\title{
Penerapan Menu Konfirmasi Pembayaran Online Berbasis Yii pada Perguruan Tinggi
}

\author{
Application of Yii Framework Online-Based Payment Confirmation Form \\ at Higher Education
}

\author{
Untung Rahardja*1, Qurotul Aini², Made Bunga Thalia ${ }^{3}$ \\ 1,2,3 Jurusan Sistem Informasi, STMIK Raharja \\ E-mail: ${ }^{1 *}$ untung@raharja.info, ${ }^{2}$ aini@raharja.info, ${ }^{3}$ bunga.thalia@raharja.info
}

\begin{abstract}
Abstrak
Sistem informasi pembayaran saat ini sudah menggunakan sistem berbasis modernisasi atau online, yang sangat dibutuhkan pada era globalisasi ini. Peranan transaksi online menjadi sangat penting bagi masyarakat modern. Seperti E-Commerce yang menjadi referensi dalam pengembangan form menu konfirmasi pembayaran pada sistem pembayaran online perguruan tinggi, dari sistem yang sebelumnya masih berjalan manual atau tidak online. Tujuan dari penelitian ini adalah untuk mengimplementasikan form menu konfirmasi pembayaran online guna meningkatkan pelayanan kepada mahasiswa perguruan tinggi dalam hal memberikan informasi pembayaran yang tepat dan akurat kepada mahasiswa, serta memberikan akses mudah bagi mahasiswa Perguruan Tinggi Raharja dalam hal konfirmasi pembayaran. Selain dapat memberikan kemudahan bagi mahasiswa, sistem ini juga dapat memberikan kemudahan untuk bagian keuangan dalam pengecekan transaksi yang sudah masuk. Sistem yang diimplementasikan pada Perguruan Tinggi Raharja untuk form menu konfirmasi pembayaran ini ialah website goplus. Website goplus ini dibangun dengan menggunakan yii2 framework, dimana sudah banyak diterapkan sebelumnya pada sistem informasi akademik lainnya di Perguruan Tinggi Raharja. Pada yii2 framework terdapat fitur CRUD (Create, Read, Update, Delete) yang dapat mempermudah dalam membuat suatu form
\end{abstract}

Kata Kunci - Form, Konfirmasi Pembayaran, Informasi, Online, YII2 Framework

\begin{abstract}
The current payment information systems already use-based systems modernization or online, which is much needed in this era of globalization. The role of online transactions is becoming very important for modern society. Like the E-Commerce as a reference in the development of the payment confirmation menu form on the college online payment system, from a system that previously still runs manually or not online. The purpose of this research is to implement online payment confirmation menu form to enhance services to college students in terms of providing payment information which is precise and accurate to college students, as well as providing easy access for students College Raharja in terms of payment confirmation. In addition to providing convenience for students, the system is also able to provide convenience to the financial section in checking of transactions already entered. The system is implemented on College Raharja to form this payment confirmation menu is goplus website. Goplus website was built using the yii2 framework, which already implemented earlier in other academic information system in College Raharja. In the yii 2 framework there are features of the CRUD (Create, Read, Update, Delete) which can make it easier to create a form.
\end{abstract}

Keywords — Form, Confirmation of Payment, Information, Online, Framework YII2 


\section{PENDAHULUAN}

Perkembangan teknologi di zaman sekarang sangatlah pesat, terutama pada perkembangan online yang memanfaatkan fasilitas internet dan terhubung dengan banyak orang di dunia. Salah satu bentuk nyata dalam perkembangan online ini adalah pada bidang pembayaran online. Pada umumnya orang-orang yang hendak membayar sesuatu harus mendatangi loket kasir untuk menyerahkan bukti transfer (jika menggunakan transfer) atau langsung bertransaksi di loket kasir, tentunya hal ini sangat tidak efisien dan efektif. Seiring dengan adanya perkembangan teknologi ini orang-orang tidak perlu lagi mengantri panjang yang menghabiskan waktu lama di loket kasir hanya untuk menyerahkan bukti transfer. Dengan memanfaatkan fasilitas form menu konfirmasi pembayaran online ini, pengguna dapat lebih efektif dan efisien dalam bertransaksi.

Sistem pembayaran adalah mekanisme dari kegiatan pemindahan dana yang terdiri dari 2 (dua) atau lebih tokoh yang bertujuan untuk memenuhi kebutuhan dan kewajiban pada masa sekarang atau masa yang akan datang [1]. Sistem pembayaran pada zaman modern ini sudah banyak diterapkan pada dunia bisnis online. Sistem pembayaran online ini disebut E-Payment, EPayment biasa digunakan pada bisnis E-commerce juga biasa dipakai pada kegiatan pembayaran di tempat yang berbeda dengan jarak yang jauh. Dengan adanya E-Payment, pengguna dengan mudah membayar menggunakan media perbankan online dan melakukan konfirmasi pembayaran langsung pada situs E-Commerce nya. Sebagai contoh dari E-Payment adalah pembayaran listrik dan air, saat ini untuk membayarkan tagihan listrik dan air costumer tidak perlu mengantri panjang pada loket, cukup pada mesin ATM (Anjungan Tunai Mandiri) terdekat, saat ini beberapa perusahaan perbankan telah memfasilitasi costumer nya dengan menu untuk pembayaran listrik dan air. Sehingga dapat disimpulkan bahwa perkembangan teknologi dalam bidang pembayaran online atau E-Payment pada zaman sekarang ini merupakan kebutuhan yang sangat penting bagi masyarakat modern dan sangat berpengaruh bagi kelangsungan hidup yang serba praktis sekarang ini.

Sistem Konfirmasi Pembayaran ini juga diterapkan pada Perguruan Tinggi Raharja. Perguruan Tinggi Raharja merupakan institusi pendidikan yang bergerak di bidang teknologi informatika. Sebagai instituisi pendidikan yang memiliki semboyan "Get The Better Future by Computer Science" tentunya manajemen Perguruan Tinggi Raharja selalu berupaya mengembangkan sistem pelayanan agar selalu bisa diterapkan menjadi lebih baik lagi dan memiliki manfaat bagi mahasiswa. Pengembangan sistem pelayanan ini ditujukan untuk kenyamanan serta kelancaran dalam proses pembayaran kuliah. Sistem Konfirmasi Pembayaran yang digunakan pada Perguruan Tinggi Raharja ini adalah salah satu fasilitas dari sistem pembayaran GO+ (goplus).

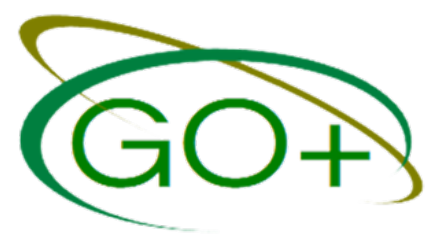

Gambar 1. Logo GO+

GO+ (Green Orchestra Plus), yang mempunyai logo seperti pada Gambar 1, merupakan sistem informasi keuangan pada Perguruan Tinggi Raharja yang berbasis online. Sistem ini dibangun sebagai media informasi untuk mahasiswa Perguruan Tinggi Raharja yang diharapkan mampu memudahkan pribadi Raharja dalam hal pengecekan biaya registrasi dan sks. Pada sistem ini terdapat menu RBK (Rincian Biaya Kuliah), RBR (Rincian Biaya Registrasi) dan Menu Konfirmasi Pembayaran, sistem ini juga dapat menampilkan informasi-informasi penting seputar pembayaran mahasiswa seperti tanggal jatuh tempo serta nomor rekening Perguruan Tinggi Raharja. Prosedur akses GO+ adalah dengan cara mahasiswa membuka situs SIS+(sisplus) pada link sisplus.raharja.ac.id terlebih dahulu dan login dengan Rinfo lalu search di kolom pencarian 
dengan kata kunci GO+ (goplus), kemudian akan langsung masuk ke link goplus.raharja.ac.id atau viewboard mahasiswa tersebut [2]. Pada viewboard mahasiswa ini akan langsung terlihat status pembayaran mereka pada semester yang berjalan, terdapat 3 (tiga) kelompok status yaitu: Unpaid (belum lunas), Installment 1(satu) (cicilan pertama) dan Paid (lunas). Jika mahasiswa sudah melakukan pembayaran, secara otomatis sistem akan memberikan email notifikasi berupa rincian pembayaran yang telah dibayarkan dan sisa pembayaran.

Sistem GO+(goplus) ini dirancang dengan menggunakan YII2 Framework, Yii Framework ini juga sudah diterapkan di sejumlah sistem yang ada pada Perguruan Tinggi Raharja, seperti PEN+ (Penilaian Plus), PENA (Penilaian Absensi), SIS+ (Student Information System Plus), PENSIL (Penilaian Absensi Asisten Lab).

\section{METODE PENELITIAN}

Dalam melakukan penelitian ini, peneliti menggunakan 2 (dua) metode penelitian. Dengan adanya metode penelitian peneliti dapat mengumpulkan informasi atau data serta melakukan investigasi terhadap informasi yang telah didapatkan tersebut.

\subsection{Metode Observasi}

Observasi merupakan suatu proses penelitian terhadap suatu sistem yang berjalan pada suatu lembaga guna mengetahui seberapa besar manfaat sistem tersebut bagi perusahaan. Pada kegiatan observasi ini, peneliti juga mengusulkan prototype pengembangan sistem terhadap stakeholder lembaga tersebut.

\subsection{Literatur Review}

Literature review adalah sebuah rangkuman atau intisari dari hasil temuan peneliti terdahulu yang dapat dijadikan sebagai acuan dalam menulis suatu artikel ilmiah atau penelitian baru mengenai suatu project [3]. Literature review ini dapat membantu peneliti dalam mendapatkan ide-ide dari hasil terdahulu untuk bisa dikembangkan menjadi lebih baik dari yang sebelumnya sudah ada.

Beberapa penelitian dilakukan mengenai sistem pembayaran pada Perguruan Tinggi. Dalam upaya memperbaiki suatu sistem pelayanan informasi yang diterapkan dan sedang berjalan pada Perguruan Tinggi Raharja, diperlukan suatu studi pustaka sebagai salah satu penerapan metode yang akan dilakukan.

Adapun penelitian pada sistem pembayaran online ini, memilliki 10 referensi dari penelitian terdahulu untuk jadi pedoman dalam penelitian pengembangan form konfirmasi pembayaran ini. Penelitian mengenai sistem penerimaan mahasiswa baru pada Bogor Hotel Institute (BHI) [4]. Menyebutkan bahwa untuk sistem penerimaan mahasiswa baru pada Bogor Hotel Institute (BHI) sudah berbasis web, namun terdapat masalah yang membuat mahasiswa luar daerah kesulitan dalam hal pendaftaran yaitu tidak adanya form konfirmasi pembayaran pada sistemnya. Pada penelitian selanjutnya mengenai sistem INT+ yang ditunjang oleh sistem GO+ (goplus) dalam pengelolaan data CMB pada Perguruan Tinggi [5]. Pada penelitian ini membahas mengenai sistem pengelolaan data calon mahasiswa baru yang juga berkesinambungan dengan GO+ (goplus) yang merupakan layanan pembayaran online pada Perguruan Tinggi Raharja, dimana system GO+ (goplus) dengan INT+ dapat memaksimalkan kinerja personil marketing. Penelitian ini dibatasi dengan adanya proses pengumpulan data yang berupa nama, email dan nomor telepon CMB (Calon Mahasiswa Baru).

Penelitian selanjutnya yang membahas mengenai implementasi terhadap email Rinfo dalam proses pembelajaran [6]. Penelitian ini menjelaskan tentang manfaat email Rinfo yang dimanfaatkan oleh seluruh civitas pada Perguruan Tinggi Raharja untuk dapat berkomunikasi secara online. Rinfo ini pun diterapkan pada system GO+ (goplus) di Perguruan Tinggi Raharja 
dengan Login SSO (Single Sign On). SSO (Single Sign On) ini sendiri diterapkan untuk lebih mempermudah anggota dalam melakukan login tanpa harus menggunakan password [7].

Selanjutnya, penelitian Sistem Informasi mengenai Penerimaan Calon Mahasiswa Baru [8]. Penelitian ini membahas mengenai suatu sistem yang dapat memberikan informasi terhadap kegiatan penerimaan mahasiswa baru (PMB). Dengan menambahkan fitur form konfirmasi pembayaran pada pendaftaran online melalui Web dan Wap, proses pendaftaran calon mahasiswa baru akan menjadi lebih mudah, hal ini juga diterapkan pada Perguruan Tinggi Raharja yaitu dengan ada nya form menu konfirmasi pembayaran tentunya sangat memudahkan mahasiswa untuk bertransaksi dan meminimalkan antrian pada loket kasir.

Penelitian berikutnya mengenai Penerapan absensi QRCode pada Mahasiswa Bimbingan Belajar [9]. Pada penelitian ini, dijelaskan bahwa penggunaan website berbasis YII framework terdapat kelebihan yaitu seperti keamanan framework dapat mengantisipasi perisai adanya berbagai permasalahan keamanan. Sama halnya dengan form konfirmasi pembayaran ini menggunakan YII Framework dalam membangun sistem nya.

Selanjutnya, penelitian mengenai E-Commerce dalam memperluas pasar produk [10]. Penelitian ini membahas mengenai keuntungan pemanfaatan e-commerce dalam upaya perusahaan dalam meminimalkan biaya operasional pemasaran, kemudahan dalam memberikan informasi seputar produk, dan transparasi harga barang serta biaya pengiriman menjadi lebih mudah, cepat dan terkontrol. Dengan adanya media online dalam pemasaran produk, tentunya dapat memberikan banyak manfaat operasional seperti hal nya pemrosesan data pemesanan produk lebih mudah untuk di lacak atau ditelusuri, sistem persediaan barang masuk dan keluar pun lebih terkontrol serta sistem pembayaran pun lebih terpantau dan akurat, sehingga hubungan dengan costumer pun menjadi baik. Penelitian ini berfokus pada transaksi pembayaran terhadap barang yang telah dipesan. Setelah pelanggan memesan barang, pelanggan harus mengisikan data pada form konfirmasi pembayaran yang telah tersedia pada sistem. Sebelum mengisi datadata yang diperlukan, hal penting yang harus costumer ketahui adalah nomor invoice. Untuk mendapatkan informasi nomor invoice, pelanggan dapat memilih menu invoice pada icon sebelah kanan website.

Dan yang terakhir penelitian mengenai Optimalisasi Business Intelligence Pada Widuri Berbasis Mediawiki Dalam Monitoring Rekapitulasi Data [11]. Penelitian ini membahas mengenai suatu website Hibah Perguruan Tinggi Raharja, merupakan website yang dibuat dan alokasikan Perguruan Tinggi Raharja untuk melayani dan memberikan informasi bagi setiap pribadi Raharja. Berbagai pengembangan dan pembaruan dilakukan oleh pengelolanya untuk dapat terus menyajikan informasi dan website yang menarik bagi pengunjung, namun pada penerapannya pengelola belum dapat mengetahui secara tepat mengenai siklus aktivitas pengunjung website. Hal ini sama dengan penerapan form konfirmasi pembayaran pada GO+, dengan adanya sistem ini tentunya dapat memberikan fasilitas berupa wadah untuk mahasiswa melakukan konfirmasi terhadap pembayaran yang telah dilakukan dan dengan adanya form konfirmasi pembayaran ini bagian keuangan dengan mudah mengetahui kegiatan pembayaran mahasiswa.

Dari 8 (delapan) Literature Review di atas, dapat disimpulkan mengenai banyaknya manfaat yang diperoleh dari system online payment untuk menunjang suatu pelayanan masyarakat dalam hal pembayaran, dan juga dengan adanya menu konfirmasi pembayaran online yang dapat memudahkan pengguna untuk lebih efektif dan efisien dalam hal memberikan informasi mengenai pembayaran yang telah di lakukan costumer untuk menunjang pelayanan system online payment ini. Namun, belum terlalu banyak jurnal atau penelitian yang hanya fokus terhadap form konfirmasi pembayaran ini. Jika dilihat pada kenyataan yang berjalan, form konfirmasi pembayaran ini sudah banyak di implemetasikan pada setiap situs belanja online. 


\section{HASIL DAN PEMBAHASAN}

\subsection{Pemecahan Masalah}

Dalam mengatasi permasalahan tersebut, diperlukan suatu tindakan dari sistem yang telah ada, yaitu dengan cara melakukan implementasi sistem sepenuhnya untuk meningkatkan pelayanan pada bagian keuangan dan memberikan kemudahan bagi mahasiswa dalam melakukan konfirmasi pembayaran.

Gambar 2 merupakan tampilan menu konfirmasi pembayaran dimana adalah tempat mahasiswa mengisi data pembayaran berupa NIM, Nama, Email, Tahun Akademik, Semester, Jumlah Tagihan, Metode, Jumlah Bayar, Tanggal Pembayaran, Nomor Rekening, Nomor Kartu, Nama Pemilik Rekening dan Bukti Foto Pembayaran.

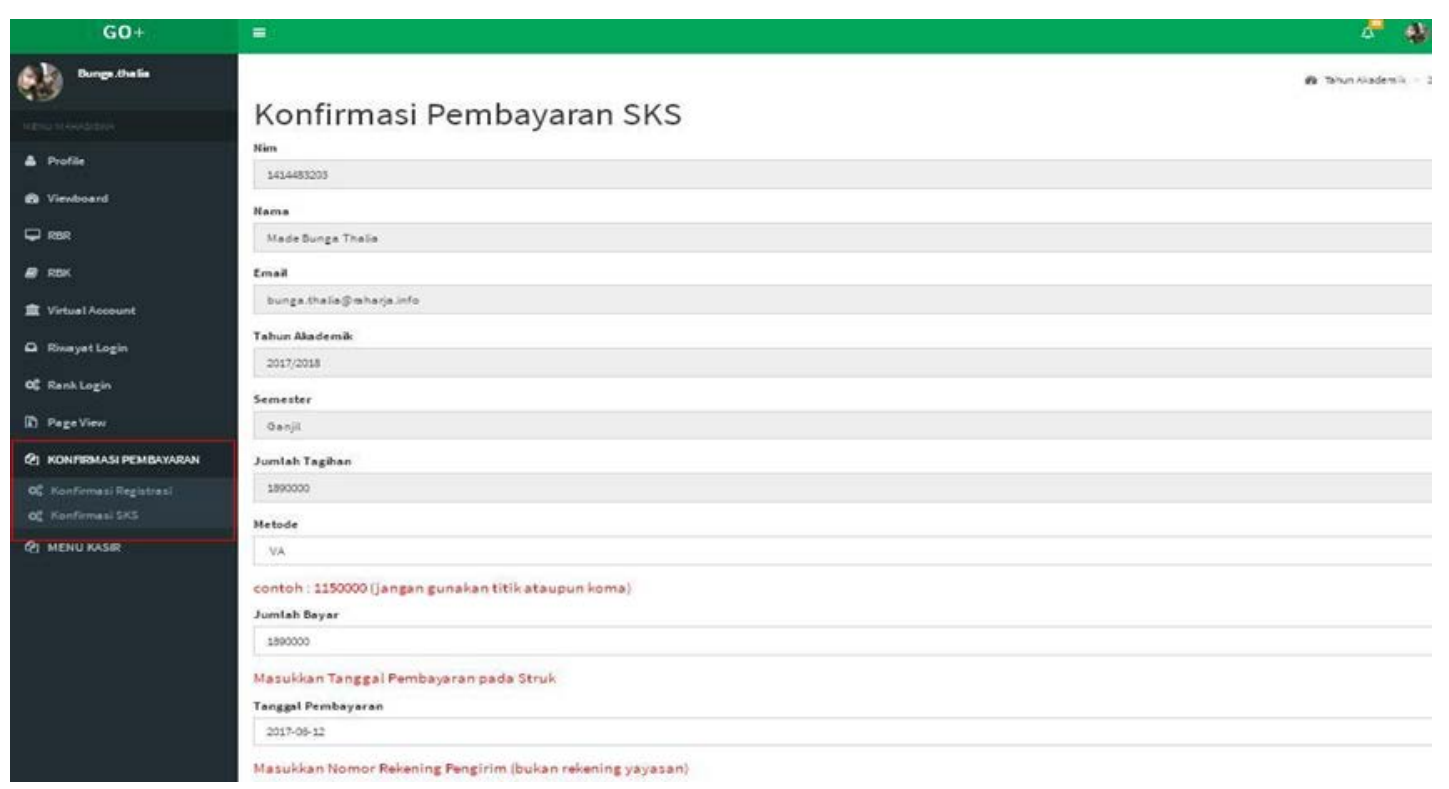

Gambar 2. Tampilan Menu Konfirmasi GO+

Dari rumusan masalah tersebut dapat disimpulkan bahwa dengan adanya konfirmasi pembayaran dapat mempermudah mahasiswa untuk melakukan konfirmasi bukti transfer dengan mengisi form konfirmasi pembayaran. Pada pemecahan masalah ini form konfirmasi pembayaran menggunakan mind mapping seperti di bawah ini.

\subsection{Mind Maping}

Pada Mind Mapping ini menghasilkan penjelasan mengenai sistem menu konfirmasi pembayaran pada GO+ (goplus) yang ada pada Perguruan Tinggi Raharja, yaitu penjelasan tentang apa itu menu konfirmasi GO+ (goplus). Menu konfirmasi GO+ (goplus) merupakan sebuah sistem pelayanan konfirmasi pembayaran mahasiswa berbasis Website. Tujuan menu konfirmasi pembayaran GO+ (goplus) adalah untuk memudahkan mahasiswa melakukan konfirmasi bukti pembayaran dengan cepat, dan juga untuk mengembangkan sistem yang sebelumnya berjalan manual menjadi online

Kelebihan dari menu konfirmasi pembayaran ini adalah dapat mengurangi antrian pada loket kasir, saat terjadi penumpukan karena adanya pembayaran jatuh tempo. Mahasiswa hanya perlu masuk ke situs goplus.raharja.ac.id dan login dengan SSO (Single Sign On) Rinfo, lalu masuk ke menu konfirmasi pembayaran kemudian isi kelengkapan data yang sudah tersedia pada form. 
Citec Journal, Vol. 4, No. 3, Mei 2017 - Juli 2017

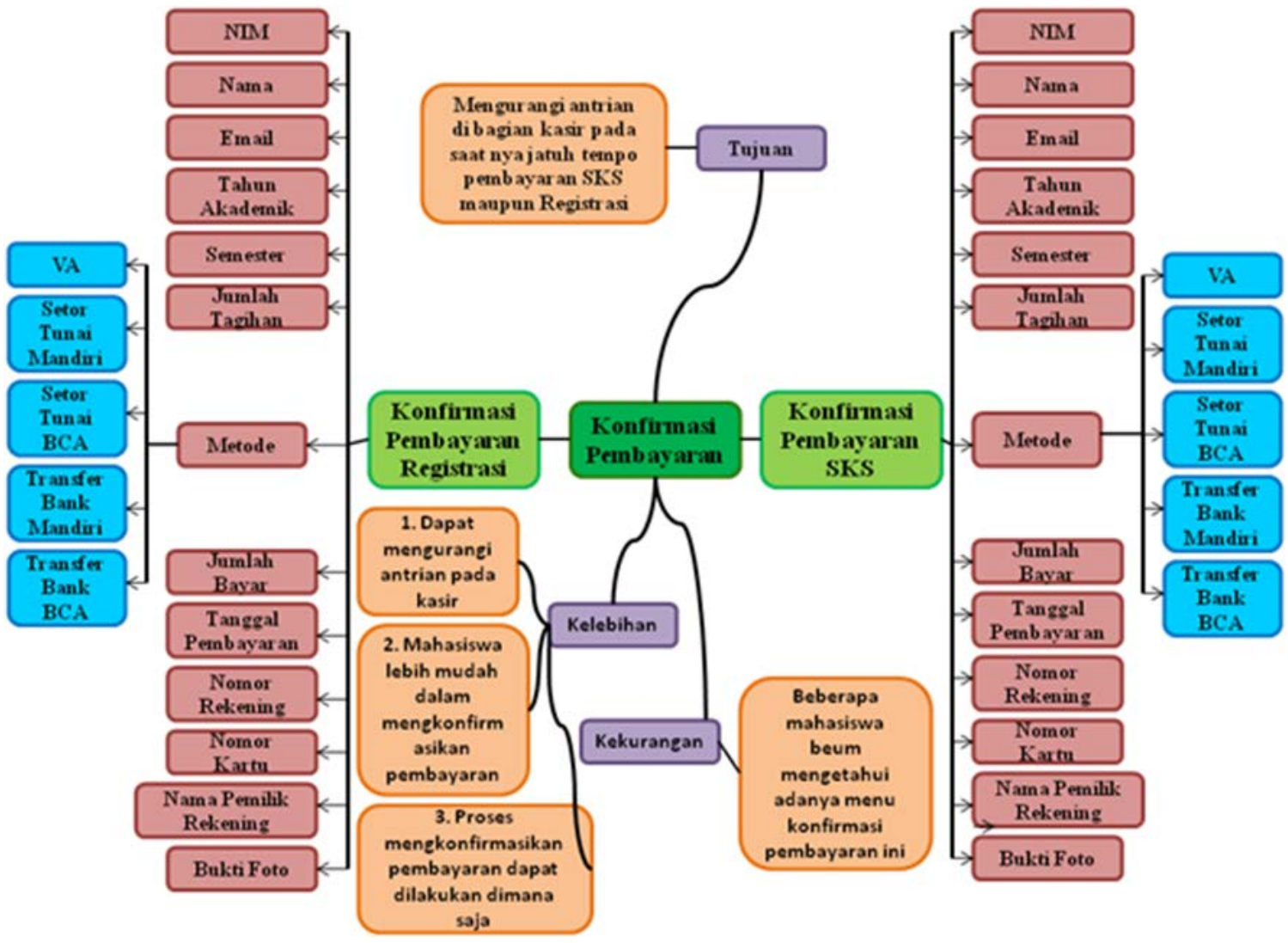

Gambar 3. Mind Mapping Menu Konfirmasi Pembayaran

\subsection{Flowchart Rancangan Aplikasi}

Flowchart program biasanya digunakan dalam sebuah pemecahan masalah dimana terdapat langkah-langkah alur program yang di jelaskan dengan berupa gambar. Gambar 4 adalah flowchart menu konfirmasi pembayaran pada GO+ (goplus). 


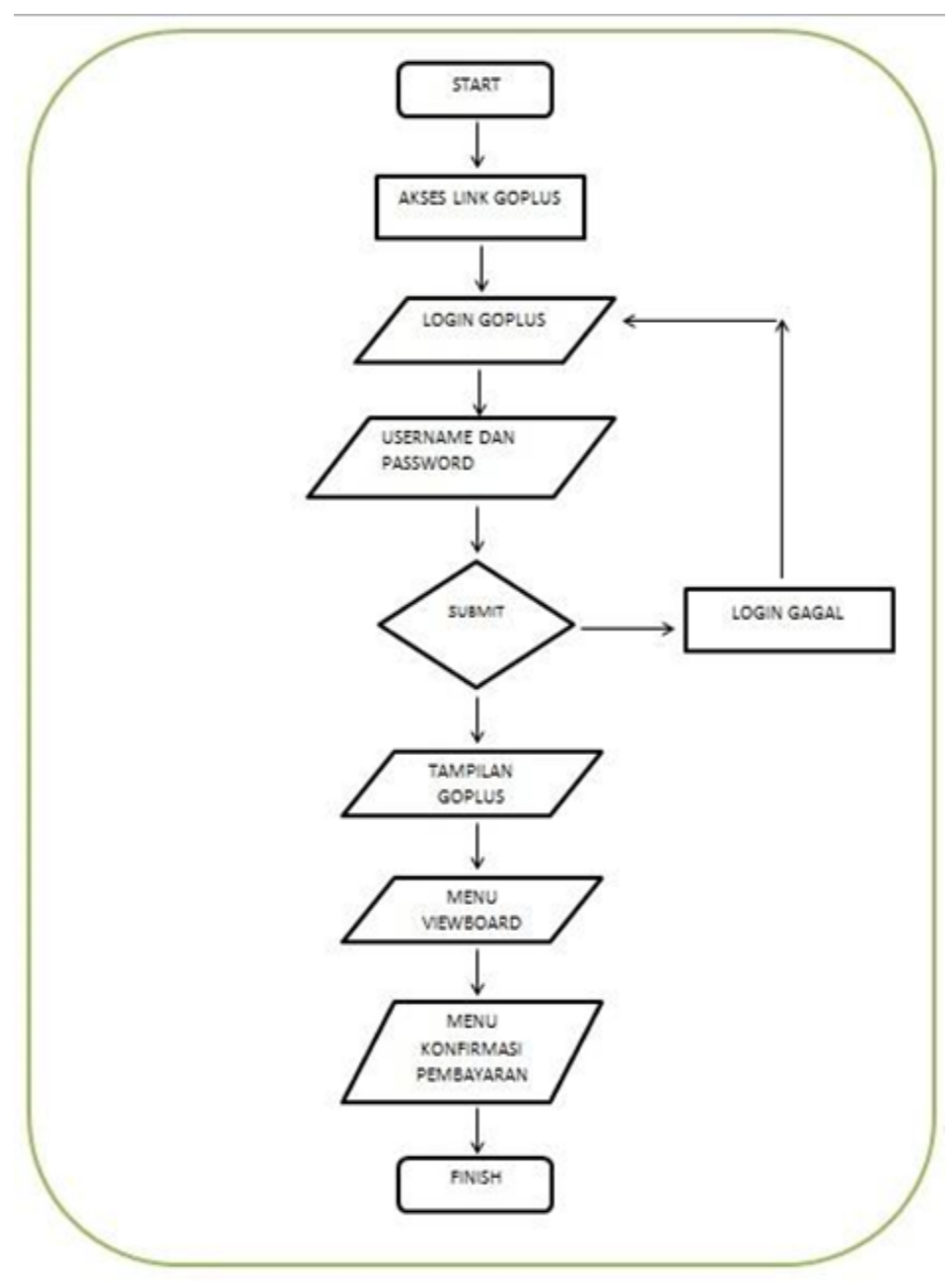

Gambar 4. Flowchart Menu

Dapat dijelaskan pada Gambar 4, flowchart program pada menu konfirmasi pembayaran terdiri dari: Dua symbol terminal, yang berperan sebagai "start" dan "finish" pada aliran proses flowchart program pada sistem menu konfirmasi pembayaran. Tujuh symbol proses yaitu menyatakan suatu tindakan (process) yang dilakukan computer. Symbol proses poster tersebut diantaranya: "akses link GO+ (goplus)" yang kemudian menuju ke "masukan username dan password" kemudian klik "submit" yang kemudian akan menuju ke "Tampilan GO+ (goplus)" lalu masuk ke "Menu Viewboard" lalu pilih menu "Konfirmasi Pembayaran”.

\subsection{Implementasi}

Implementasi pada sistem ini dibuat oleh pengguna pada sistem goplus yang mana juga diterapkan di Perguruan Tinggi Raharja sebagai sistem keuangan yang memberikan fasilitas kepada mahasiswa dan staff bagian keuangan. 
Citec Journal, Vol. 4, No. 3, Mei 2017 - Juli 2017

ISSN: 2460-4259

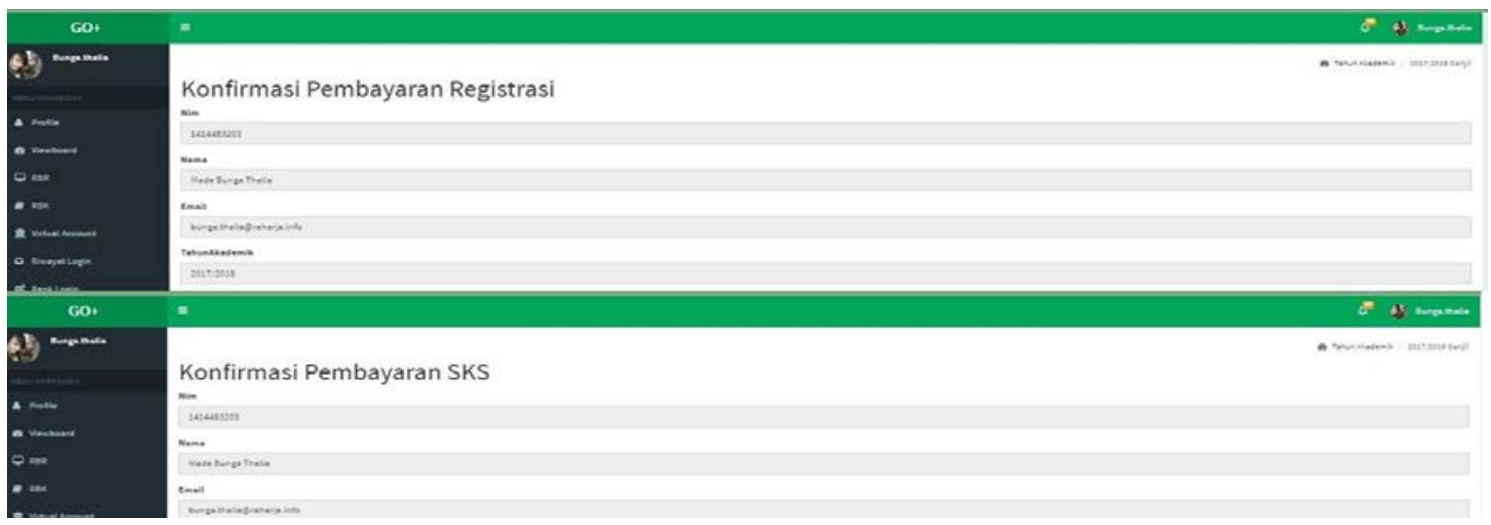

Gambar 5. Menu Konfirmasi Pembayaran GO+.

Gambar 5 merupakan tampilan utama pada menu konfirmasi pembayaran, form menu konfirmasi pembayaran ini menyatakan bahwa data mahasiswa tersebut benar, dapat dilihat dari NIM (Nomor Induk Mahasiswa) dan nama mahasiswa yang tertera pada menu. Pada Gambar 6 menunjukkan coding pada form menu konfirmasi pembayaran.

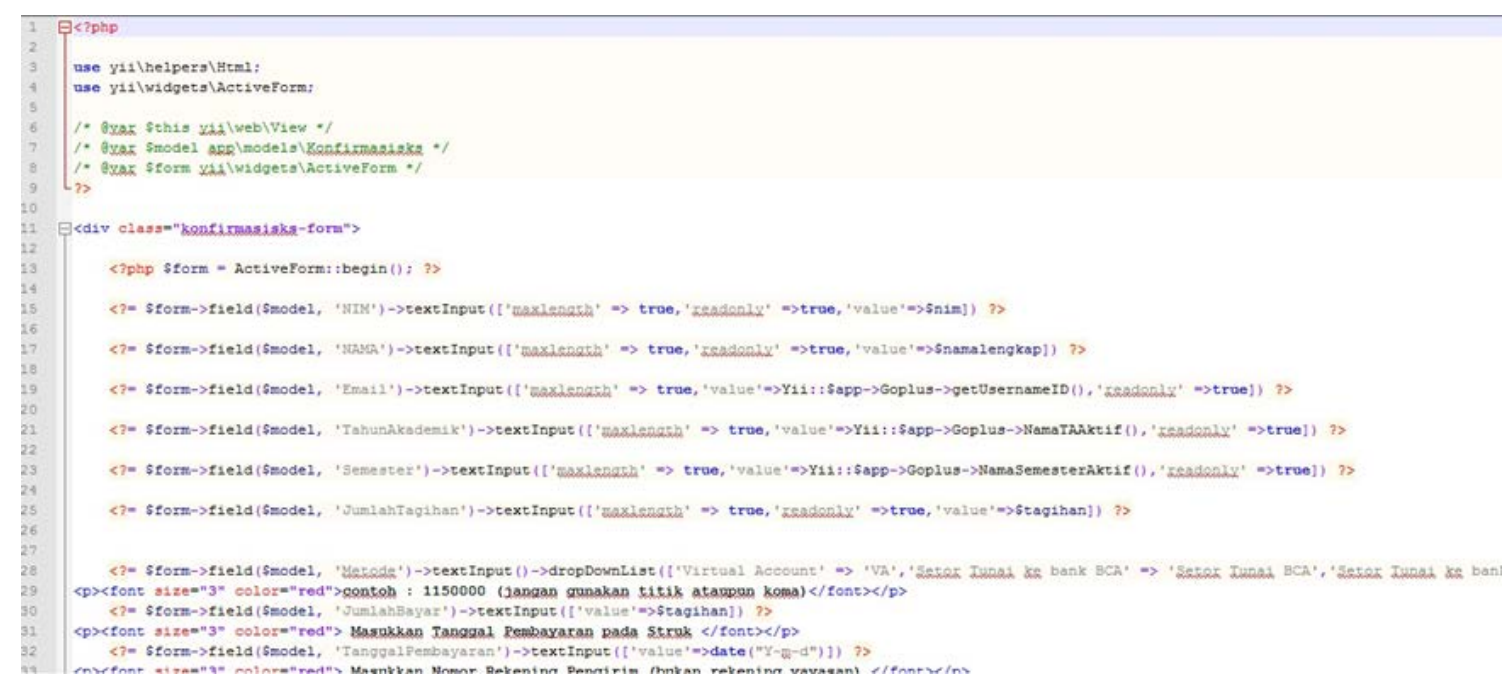

Gambar 6. Coding Menu Konfirmasi Pembayaran GO+

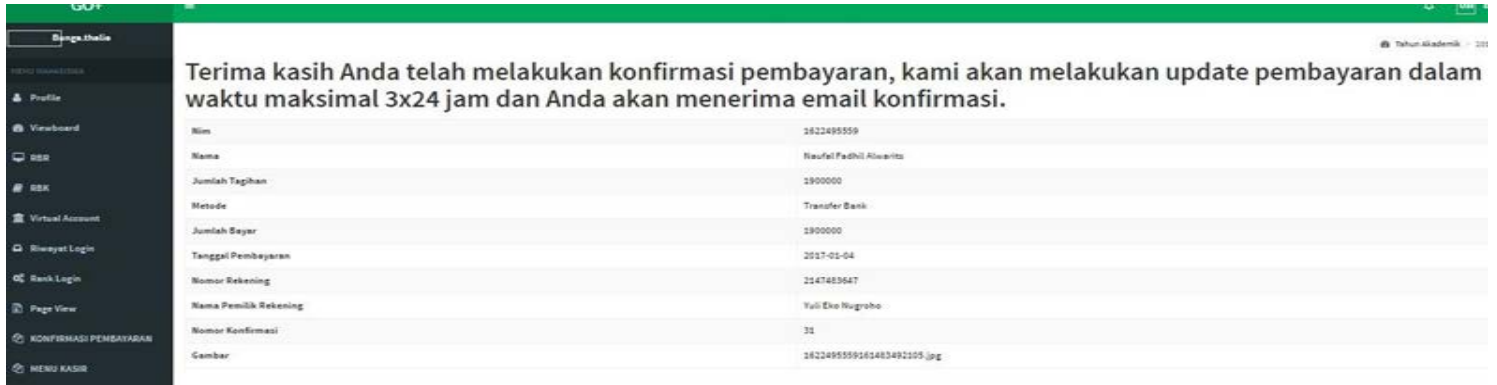

Gambar 7. Pemberitahuan Konfirmasi Pembayaran GO+

Gambar 7, menjelaskan tentang tampilan menu utama pada menu konfirmasi pembayaran, pada gambar tersebut menyatakan bahwa benar data mahasiswa tersebut, dapat dilihat dari NIM (Nomor Induk Mahasiswa) dan nama mahasiswa yang tertera pada menu. Coding pada data invoice konfirmasi pembayaran bias dilihat pada Gambar 8. 


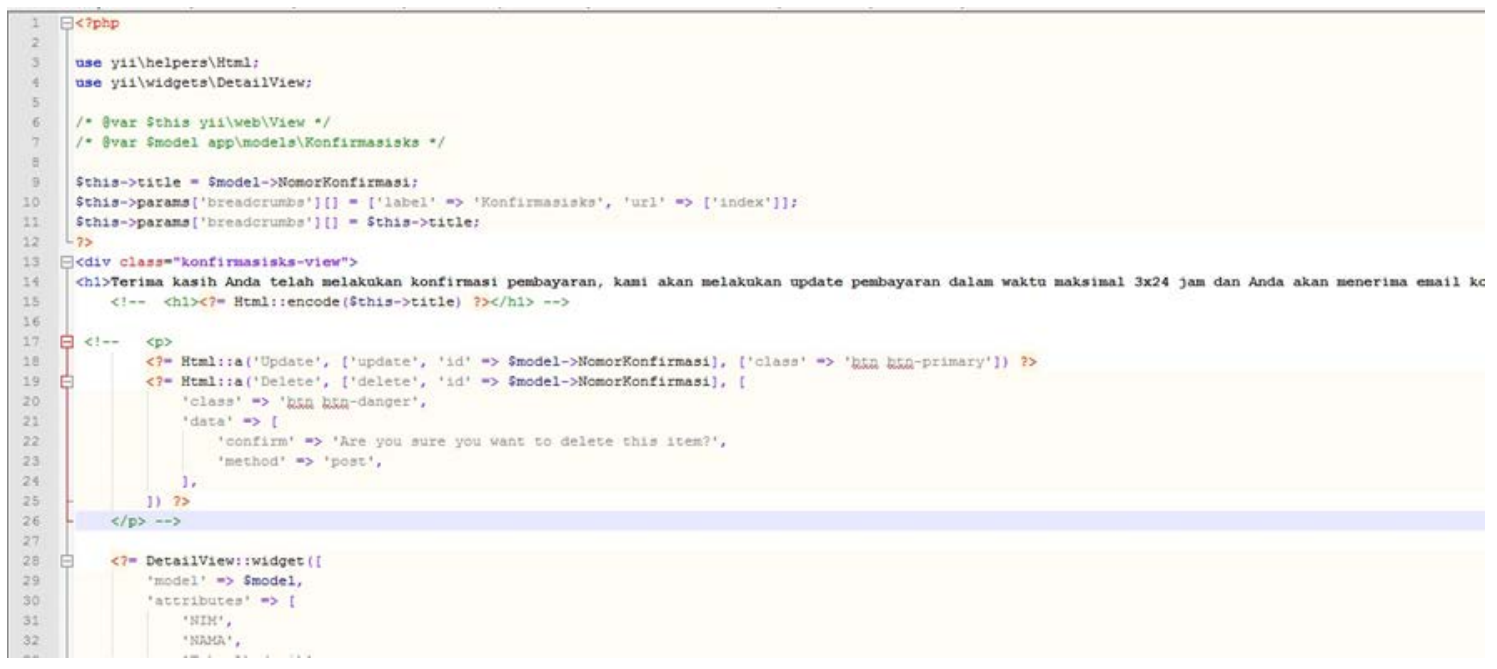

Gambar 8. Coding Tampilan Data Invoice Konfirmasi

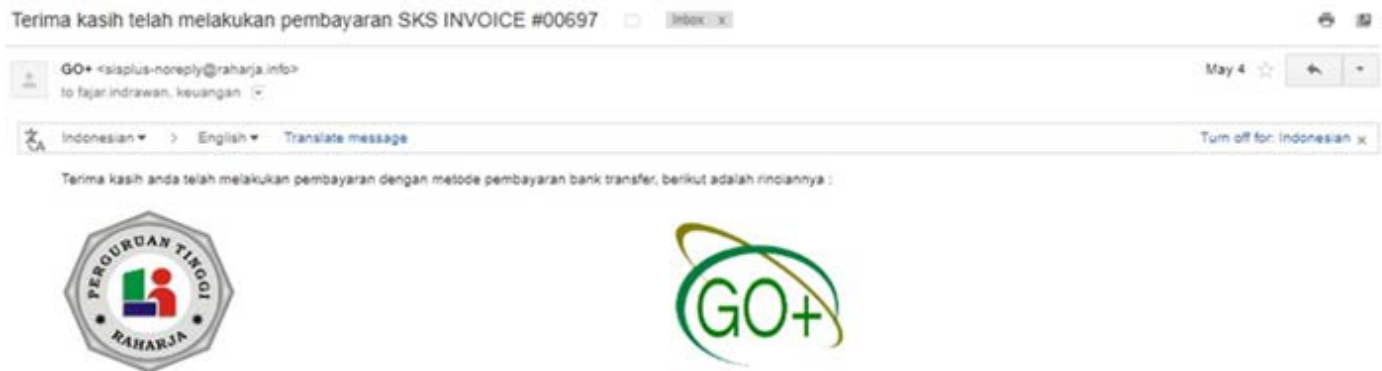

INVOICE \#00697

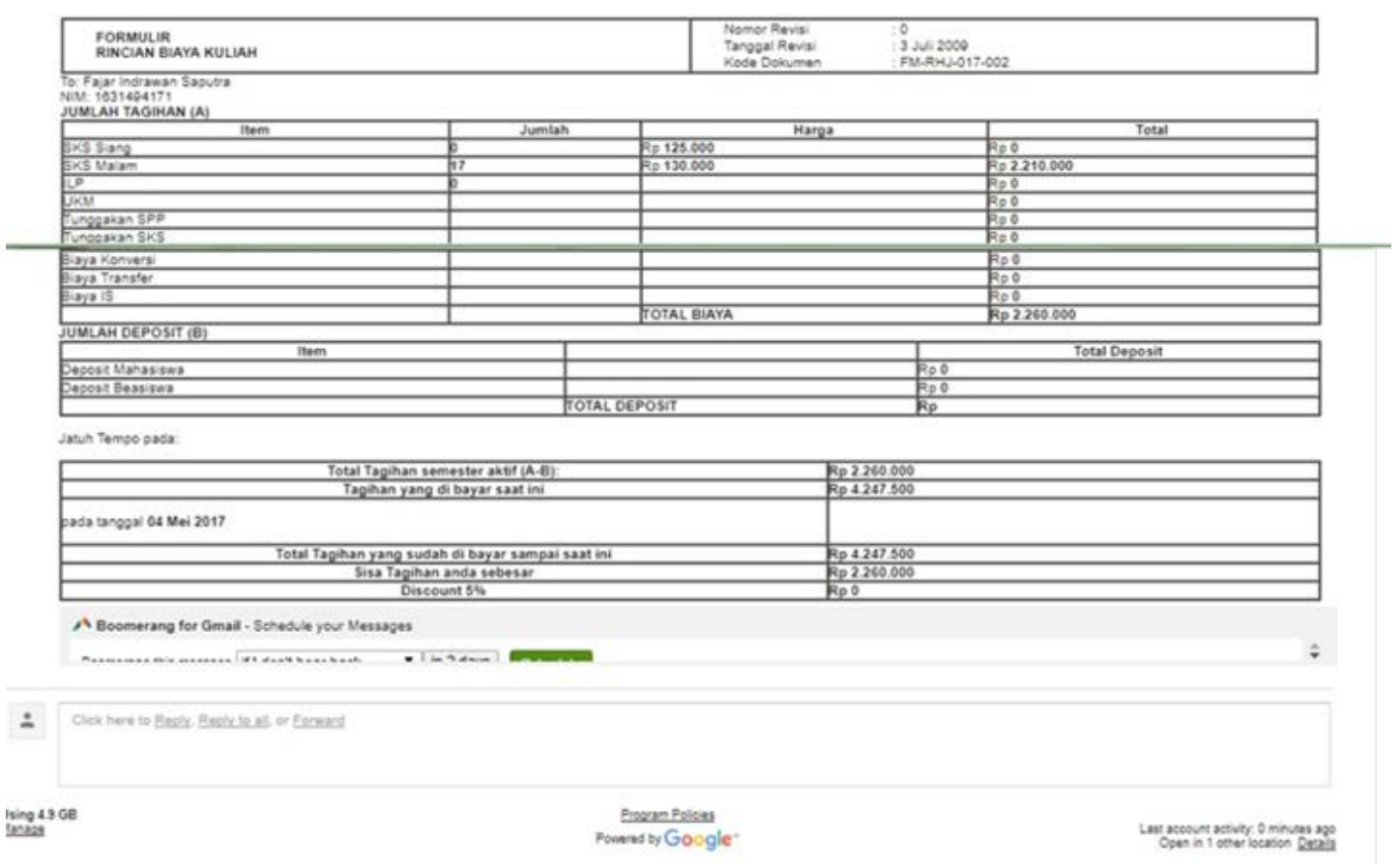

Gambar 9. Pemberitahuan Konfirmasi Pembayaran GO+ via Email 
Gambar 9, menjelasan tentang tampilan rincian pembayaran dan sisa pembayaran mahasiswa. Setelah staff keuangan klik create, kemudian mahasiswa mendapatkan email dari $\mathrm{GO}+$ (goplus) berupa rincian pembayaran yang telah di kirimkan melalui menu konfirmasi pembayaran.

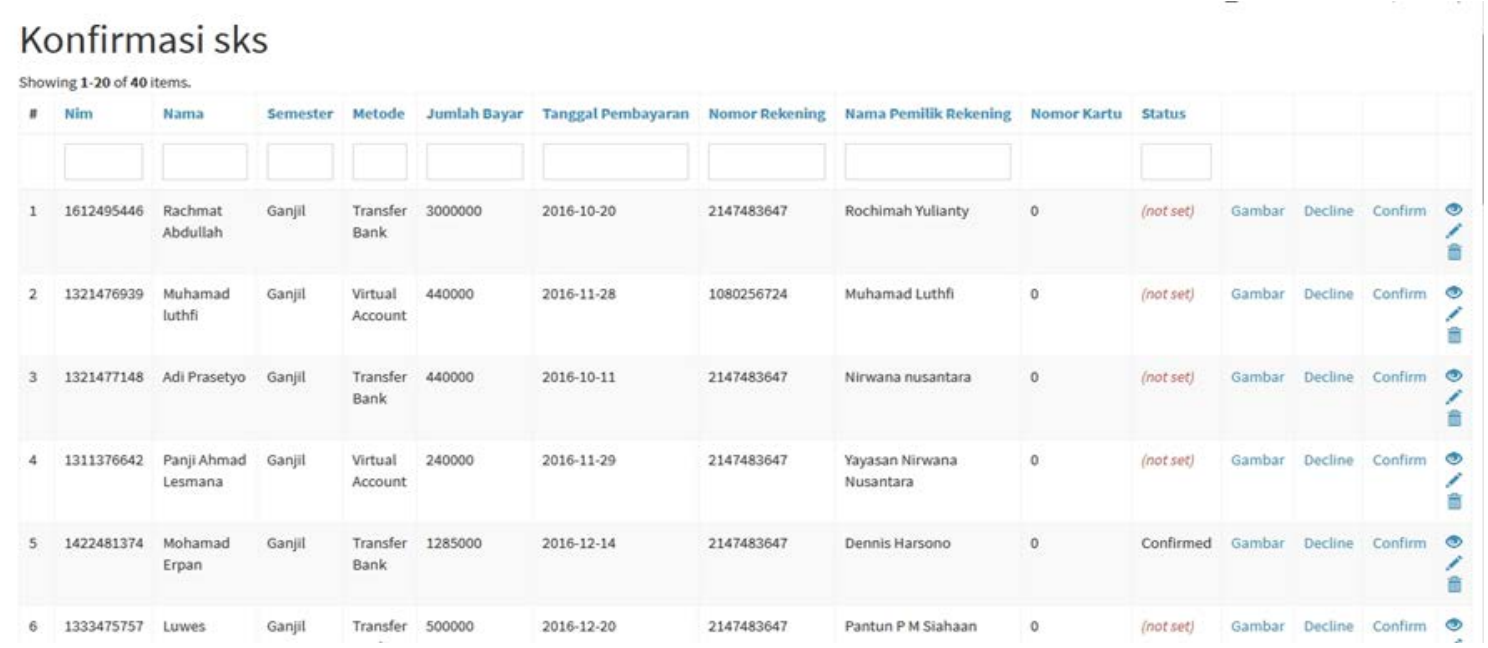

Gambar 10. Rekapan Inputan Konfirmasi Pembayaran SKS

Gambar 10, menjelaskan tentang urutan tampilan data mahasiswa yang melakukan input konfirmasi pembayaran SKS pada menu kasir dan masuk pada sistem kasir.

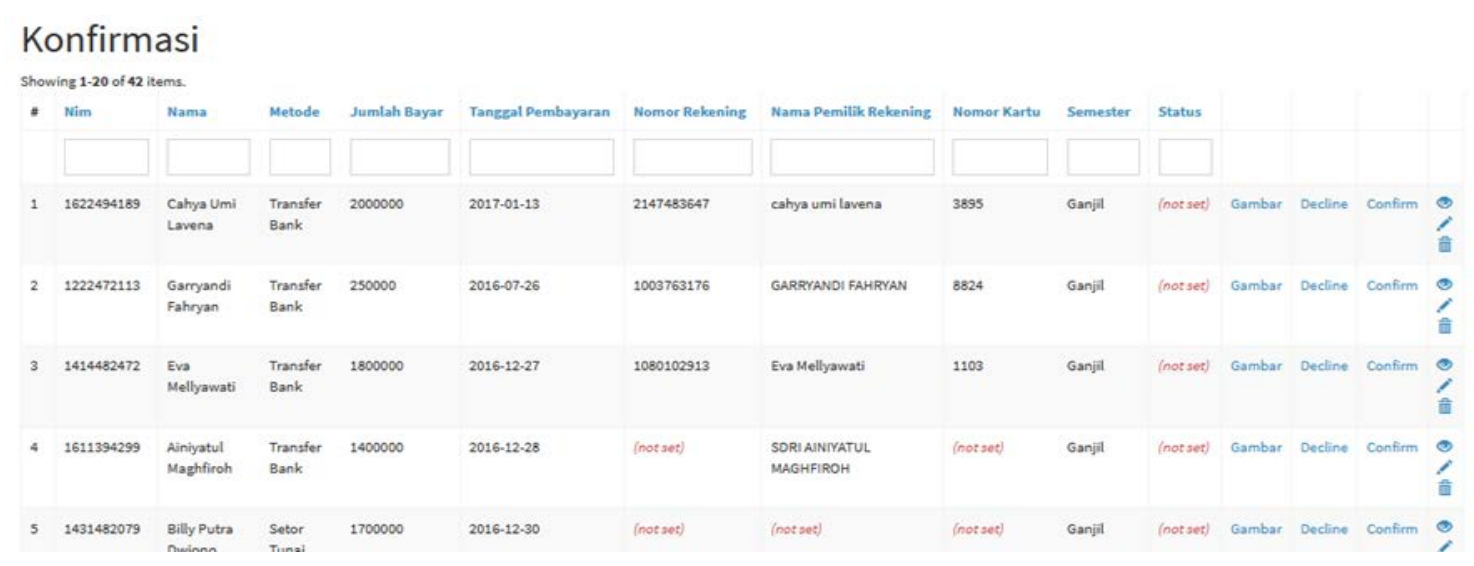

Gambar 11. Rekapan Inputan Konfirmasi Pembayaran Registrasi

Gambar 11, menjelaskan mengenai tampilan data mahasiswa yang menginput konfirmasi pembayaran registrasi pada menu kasir dan masuk pada sistem kasir.

\section{KESIMPULAN}

Berdasarkan permasalahan pada pendahuluan di atas dapat disimpulkan, penelitian ini menggunakan metode observasi, literature review, dan mind mapping. Menggunakan sistem menu konfirmasi ini secara online menjadi lebih praktis dan efisien sehingga dapat meminimalkan antrian yang menumpuk pada bagian kasir, juga memudahkan staff kasir dalam hal menerima bukti pembayaran yang diinput oleh mahasiswa dan mendata setiap transaksi yang masuk ke dalam data SKS/Registrasi. Dengan adanya sistem menu konfirmasi pembayaran ini diharapkan mampu memberikan mutu pelayanan yang baik bagi mahasiswa dan juga staff bagian keuangan juga dapat memberikan informasi akurat baik bagi mahasiswa dan bagi staff keuangan 
mendapatkan informasi mengenai hasil transaksi sesuai kebutuhannya. Sistem konfirmasi pembayaran ini memiliki kelebihan dan kekurangan, diantaranya:

1. Kelebihan:

a. Menu konfirmasi pembayaran ini menggunakan website sehingga memudahkan user untuk mengakses nya kapanpun dan dimanapun.

b. Berbasis online, baik melalui PC/Laptop atau Gadget yang dimiliki.

c. Terdapat pilihan metode pembayaran dan jumlah pembayaran guna memudahkan user untuk memberikan informasi transaksi pembayaran yang ingin di konfirmasikan.

d. Terdapat tampilan menu hasil input oleh user sehingga dapat melihat kembali kebenaran data yang dimasukan oleh user.

e. Berbasis online, baik melalui PC/Laptop atau Gadget yang dimiliki.

2. Kekurangan:

a. Menu konfirmasi pembayaran ini sedang dalam tahap implementasi

b. Fitur kurang, masih harus menambah fitur-fitur pendukung seperti link button IduHelp.

\section{SARAN}

Sistem Konfirmasi Pembayaran yang sudah diterapkan ini alangkah baiknya jika digunakan semaksimal mungkin oleh mahasiswa dan bagian keuangan. Karna manfaat dari sistem ini sangat baik bagi perkembangan teknologi masa kini, dan juga untuk meningkatkan pelayanan mengenai pembayaran bagi mahasiswa Perguruan Tinggi.

\section{DAFTAR PUSTAKA}

[1] Azka, A., Saputro, M, E., 2017. Pengaruh Penggunaan Alat Pembayaran Menggunakan Kartu Terhadap Jumlah Uang Beredar Di Indonesia (Periode 2009-2016), Skripsi, fakultas Ekonomi dan Bisnis Islam, IAIN Surakarta.

[2] Putri, F, M., 2017, Pengembangan Sistem GO+ Berbasis YII2 Framework Sebagai Media Informasi Untuk Kepala Divisi Keuangan Pada Perguruan Tinggi, Skripsi, Jurusan Sistem Informasi, STMIK RAHARJA, Tangerang

[3] Hasibuan, A, Z., 2007, Metodologi Penelitian Pada Bidang Ilmu Komputer Dan Teknologi Informasi : Konsep, Teknik dan Aplikasi, Jurnal Fakultas Ilmu Komputer Universitas Indonesia.

[4] Afriazy, Bayu, 2011, Sistem Penerimaan Mahasiswa Baru Berbasiskan Website Pada Bogor Hotel Institute (BHI), Skripsi, Fakultas Ilmu Komputer dan Teknologi Informasi, Universitas Gunadarma

[5] Yusup, M., Rahardja, U., dan Oktaviani, S., 2018. GO+ Dalam Menunjang Int+ Untuk Pengelolaan Data Cmb Pada Perguruan Tinggi, CCIT Journal, No.1, Vol.8, Hal. 65-82.

[6] Rahardja, U., Tiara, K. dan Wijaya, R.I.T., 2014. Penerapan Rinfo Sebagai Media Pendukung Untuk Proses Pembelajaran Pada Perguruan Tinggi Raharja. Jurnal CCIT, No.1, Vol 8, Hal 101-115

[7] Rahardja, U., Fadillah, I., Lestari, W., 2016. Penggunaan System Single Sign On (SSO) Dalam Mendukung Kemajuan pada Forum Rhjfox di Perguruan Tinggi Raharja, Seminar Nasional Sistem Informasi dan Teknologi, Makassar, 17 Desember.

[8] Wijaya, S. W. S., Mulyanto, A., dan Mustakim, M., 2010. Sistem Informasi Penerimaan Mahasiswa Baru Berbasis WEB dan WAP, Seminar Nasional VI, Yogyakarta, 18 November. 
Citec Journal, Vol. 4, No. 3, Mei 2017 - Juli 2017

[9] Aini, Q., Graha, Y. I., dan Zuliana, S. R., 2017. Penerapan Absensi QRCode Mahasiswa Bimbingan Belajar pada Website berbasis YII Framework. SISFOTENIKA, , No. 2, Vol. 7 Hal. 207-218.

[10] Kosasi, S., 2015, Perancangan dan Pemanfaatan E-Commerce Untuk Memperluas Pasar Produk Furniture, Seminar Nasional Teknologi Informasi dan Komunikasi 2015 (SENTIKA 2015), Yogyakarta, 28 Maret.

[11] Tiara, K., Nurhayati, S., Heriyani, N., 2016. Optimalisasi Business Intelligence Pada Widuri Berbasis Mediawiki Dalam Monitoring Rekapitulasi Data. Creative Information Technology Journal, No. 1, Vol. 4, Hal.72-81 